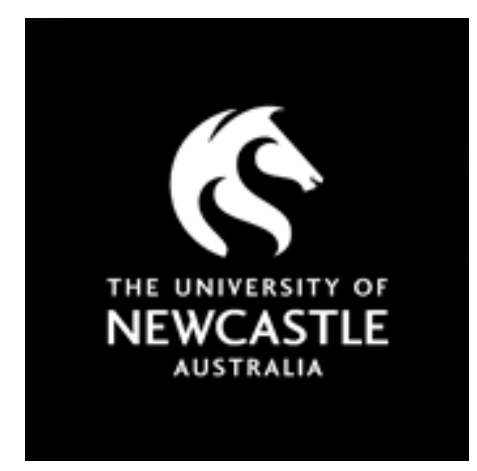

\title{
NOVA
}

University of Newcastle Research Online

nova.newcastle.edu.au

Skelding, Kathryn A.; Rostas, John A. P. "Regulation of CaMKII in vivo: the importance of targeting and the intracellular microenvironment ". Originally published in Neurochemical Research Vol. 34, Issue 10, p. 1792-1804

Available from: http://dx.doi.org/10.1007/s11064-009-9985-9

The original article is available at www.springerlink.com

Accessed from: http://hdl.handle.net/1959.13/916440 


\section{Regulation of CaMKII In Vivo: the Importance of Targeting and the Intracellular Microenvironment}

Kathryn A. Skelding and John A.P. Rostas*

School of Biomedical Sciences and Hunter Medical Research Institute,

Faculty of Health, The University of Newcastle,

Callaghan, New South Wales 2308, Australia

* Address for Correspondance:

John A.P. Rostas

Faculty of Health, Bowman Building, The University of Newcastle, University Drive,

Callaghan, New South Wales 2308, Australia

Email: John.Rostas@newcastle.edu.au

Telephone: +61249215615

Fax: + 61249215669

Running Title: Regulation of CaMKII In Vivo

Key Words: calcium/calmodulin, molecular targeting, cell signalling, protein phosphorylation, CaMKII 


\begin{abstract}
CaMKII (calcium/calmodulin-stimulated protein kinase II) is a multifunctional protein kinase that regulates normal neuronal function. CaMKII is regulated by multi-site phosphorylation, which can alter enzyme activity, and targeting to cellular microdomains through interactions with binding proteins. These proteins integrate CaMKII into multiple signalling pathways, which lead to varied functional outcomes following CaMKII phosphorylation, depending on the identity and location of the binding partner. A new phosphorylation site on CaMKII (Thr253) has been identified in vivo. Thr253 phosphorylation controls CaMKII purely by targeting, does not effect enzyme activity, and occurs in response to physiological and pathological stimuli in vivo, but only in CaMKII molecules present in specific cellular locations. This new phosphorylation site offers a potentially novel regulatory mechanism for controlling functional responses elicited by CaMKII that are restricted to specific subcellular locations and/or certain cell types, by controlling interactions with proteins that are expressed in the cell at that location.
\end{abstract}




\section{INTRODUCTION}

Calcium/calmodulin-stimulated protein kinase II (CaMKII) is a family of multifunctional serine (Ser)/threonine (Thr) protein kinases encoded by four genes ( $\alpha$, $\beta, \gamma, \partial$ ) [1]. One or more members of this family are found in virtually every tissue, and mediate diverse physiological responses triggered by increases in intracellular calcium concentrations, activation by the binding of calcium/calmodulin and the ability to undergo autophosphorylation. CaMKII is expressed most abundantly in neurons, and is involved in regulating many aspects of neuronal function, including neurotransmitter synthesis and release, modulation of ion channel activity, cellular transport, cellular morphology and neurite extension, long-term plasticity, learning, memory consolidation, and memory erasure following retrieval [2-7]. Non-neuronal CaMKII has been implicated in the regulation of other biological processes, such as fertilisation [8], osteogenic differentiation [9], and the maintenance of vascular tone [10]. Aside from its abundance in the brain, intense interest in CaMKII arose from its ability to act as autophosphorylatable molecular switch (reviewed in [11, 12]).

Due to its abundant expression in neurons and its importance in regulating various neuronal functions, it is perhaps not surprising that CaMKII has been shown to play important roles in neuronal pathology. Genetically modified animals with altered CaMKII regulation, expression level, or subcellular distribution demonstrate impaired learning and altered synaptic physiology [13]. Animal models of transient global or focal ischemia exhibit changes in CaMKII that are early in onset and long lasting [1416]. Similarly, alterations in CaMKII phosphorylation have been observed in the brains of patients with Alzheimer's disease [17], and CaMKII is involved in the phosphorylation of tau and amyloid precursor protein [18, 19], two proteins important 
in the pathogenesis of Alzheimer's disease. CaMKII has also been implicated in epileptogenesis [20], and genetically modified mice with mutations that prevent phosphorylation at Thr305/306 on CaMKII $\alpha$ are more susceptible to seizures [13]. Phosphorylation of CaMKII has also been demonstrated to be a critical contributor to the spontaneous/ongoing component of tissue-injury evoked persistent pain [21]. In an animal model of Parkinson's disease, changes in CaMKII phosphorylation in the striatum have a causal role in the alterations of motor behaviour and striatal plasticity that follow dopaminergic denervation [22].

The present review briefly summarises current knowledge on the structure and regulation of CaMKII, but focuses on how the molecular environment and interaction with binding partners can influence the function of CaMKII. Emerging evidence arising from several laboratories has shown that the present understanding of CaMKII regulation in vivo is inadequate, and that additional regulatory mechanisms must exist. A new phosphorylation site in vivo at Thr253 has recently been discovered that, interestingly, does not alter CaMKII activity. Thr253 phosphorylation does, however, alter the interactions of CaMKII with binding protein partners, which appear to determine the functional outcomes in a way that varies with the intracellular microenvironment in which the kinase is found.

\section{STRUCTURE AND ISOFORMS}

Each isoform of CaMKII can be divided into three domains: a C-terminal association domain, a N-terminal catalytic domain, and a regulatory domain in between (Figure 1). The sequence of amino acids $282-300$ (numbered according to the $\alpha$ isoform) within the regulatory domain is known as the autoinhibitory domain because it 
interacts with the catalytic domain to block the ATP binding site, and inhibits the kinase activity of the enzyme [23, 24]. The amino acid sequence 293 - 310 binds calcium/calmodulin and partially overlaps with the autoinhibitory domain [25]. Consequently, binding of calcium/calmodulin to the calmodulin binding site disrupts the interactions between the autoinhibitory and catalytic domains [24]. There are four main variable regions $(\mathrm{V} 1-4)$ through which alternative splicing produces more than 30 isoforms from the four genes by alternative splicing. The V1 region, located between the regulatory and association domains, is the primary site for divergence among the four genes of CaMKII [26].

CaMKII isoforms are not uniformly expressed in all tissues. $\alpha$ and $\beta$ are primarily localised to nervous tissue [1], whereas $\gamma$ and $\partial$ are found at low levels in virtually all tissues [27]. Individual cells vary in their pattern of CaMKII isoform expression and can contain more than one isoform. Different isoforms can co-assemble into heteromeric holoenzymes [28], so it is likely that both homomultimers and heteromultimers of CaMKII exist in vivo [29-32]. Homomeric CaMKII composed of different isoforms exhibit distinct calmodulin concentration dependences for autophosphorylation, which results from differences in their affinity for calmodulin [30], and also show significant variations in autophosphorylation rate and substrate phosphorylation [33]. These results suggest that heteromeric CaMKII should display varied functional properties depending on its subunit composition, but this prediction remains to be tested.

\section{Figure 1 here}


The three-dimensional structure of CaMKII has been examined by computer-assisted analysis of electron microscopy images. Early studies using CaMKII purified from various animal tissues or baculovirus overexpression systems demonstrated that the association domains formed an annular structure with a hole in the centre, and that the catalytic and regulatory domains were arranged around the association domain core [31, 33-35]. Gaertner et al [33] and Kanaseki et al [31] proposed that the CaMKII holoenzyme consisted of two 'wheels' of six catalytic and regulatory domains which are tethered to a central tube formed by the twelve association domains ('hub-andspoke' model), whereas Morris and Torok [35] suggested that there is actually an outer ring of 12 catalytic and regulatory domains, rather than two 'wheels' of six. The controversy was resolved by Rosenberg et al [36], who utilised the higher resolution SAXS (small angle x-ray scattering), which showed that the structure is in fact highly unusual. The CaMKII $\alpha$ crystal is an asymmetric unit that consists of two autoinhibited catalytic domains in a symmetric dimer held together by interactions between anti-parallel coiled-coil structures formed by the regulatory domains. The regulatory domains are joined by a hinge to the $\mathrm{C}$ terminus of the catalytic domain. The regulatory domain functions like a gate (with Thr286 as its hinge), so that it is positioned to block the protein substrate and ATP binding sites when CaMKII is autoinhibited, and is 'open' when CaMKII is autophosphorylated at Thr286. Therefore, CaMKII is comprised of six mutually inhibited dimers. Homomers of $\alpha, \beta$, $\gamma$, and $\partial$ all exhibit the same basic structure. Whilst heteromultimers are known to exist [28], their structures are unknown.

These findings highlight the unique structure of CaMKII, and predict properties that are known to be important for the function of the kinase. For instance, if the dimer is 
the basic unit of the holoenzyme, the binding of the first calmodulin to one kinase domain would remove its interaction with the regulatory domain of the second kinase domain, making the second calmodulin-binding site more accessible. This would account for the observed co-operative nature of calcium/calmodulin binding to the holoenzyme [36].

\section{REGULATION OF CaMKII}

The biological properties of CaMKII are regulated by multi-site phosphorylation and targeting to specific subcellular locations through interactions with proteins. These two control mechanisms can also influence one another, as the interaction between CaMKII and some binding partners can be modified by the phosphorylation state of the kinase, and vice versa. The effects of autophosphorylation on kinase activity have been studied extensively with purified CaMKII in vitro but the mechanisms of, and functions mediated by, targeting are less well understood. Emerging evidence indicates that the behaviour of CaMKII in vitro does not always correctly predict behaviour in vivo, and that there are extra control mechanisms operating in vivo that are only just beginning to be appreciated.

\section{Autophosphorylation}

Purified CaMKII requires the presence of both calcium and calmodulin for initial enzyme activity. Autophosphorylation of Thr286 in CaMKII $\alpha$ (Thr287 in CaMKII $\beta$, $\gamma$, and $\partial$ ) occurs quickly and produces changes in the affinity for calcium/calmodulin, enzyme activity, and targeting to specific subcellular sites (Table 1). The major effects of Thr286 phosphorylation are: 
1. CaMKII phosphorylated at Thr286 has a 1000-fold increase in the affinity for calcium/calmodulin, which prolongs the calcium/calmodulin stimulated activity of CaMKII because calmodulin is slower to dissociate from the enzyme once the intracellular concentration of free calcium returns to the basal state (calmodulin 'trapping') [37]. The interaction between CaMKII and calmodulin is considerably different than that between calmodulin and other calmodulin-binding proteins [38, 39], with CaMKII possessing one of the lowest affinities for calmodulin when compared to other calmodulin-binding proteins (reviewed in [40]). Therefore, despite its abundance, under basal conditions CaMKII will be one of the last calciumsensitive enzymes to be activated by a rise in intracellular calcium. However, after autophosphorylation at Thr286, CaMKII exhibits one of the highest affinities for calmodulin.

2. CaMKII phosphorylation at Thr286 allows the enzyme to remain active even after calmodulin has dissociated from it (autonomous activity). Calcium/calmodulin binding activates CaMKII by disrupting the interaction between the autoinhibitory domain and the ATP and protein substrate binding sites (reviewed in [12, 26, 40]), allowing the kinase to phosphorylate both itself and its substrates. Autophosphorylation of Thr286 requires calcium/calmodulin binding to adjacent subunits in a single holoenzyme and results in transautophosphorylation of Thr286 between the adjacent subunits, both of which have calmodulin bound [37]. As a result of the combined effects of calmodulin 'trapping', autonomous activity and the requirement for activation of adjacent subunits, CaMKII is able to decode the frequency, amplitude and duration of calcium spikes into graded responses of kinase activity [41]. 
3. Autophosphorylation of CaMKII at Thr286 can also regulate the function of the enzyme by increasing the binding of CaMKII to specific subcellular sites, such as the post-synaptic density (PSD) [37, 42, 43] (Table 1). This allows the targeting of CaMKII to specific sites, thereby selectively regulating downstream functions following CaMKII activation.

\section{Table 1 here}

Once the kinase activity of CaMKII is calcium-independent (autonomous), secondary sites that are within the calmodulin-binding site can be phosphorylated (Thr305/306 in CaMKII $\alpha$, and Thr306/307 in CaMKII $\beta$, $\gamma$, and $\partial$ ). Thr305/306 are adjacent amino acids, either one or both of which can be phosphorylated in different isoforms under different conditions [44, 45]. These sites are inaccessible when calmodulin is bound and so can only be autophosphorylated by autonomously active CaMKII subunits. Once these sites are phosphorylated, calmodulin can no longer bind so CaMKII cannot be activated by calcium/calmodulin and the activity of the enzyme becomes insensitive to changes in calcium/calmodulin [46]. Although Thr305/306 have been called ‘inhibitory’ sites, this name is somewhat misleading as rapid phosphorylation of these sites only occurs in kinase that is autonomously active as a result of Thr286 phosphorylation, and the Thr305/306 phosphorylation has no effect on the autonomous activity. Thr305/306 can also be phosphorylated at a very slow basal rate in vitro by non-phosphorylated CaMKII in the absence of calcium/calmodulin [47]. If this also occurs in the intracellular environment, which is not known, 
CaMKII may become phosphorylated in vivo to some basal level in the absence of calcium spikes.

Recently, the consequences of phosphorylation at Thr253 have begun to be characterised. This phosphorylation site, which is present in every subunit and conserved across species, has been shown to be phosphorylated in vivo [48]. As shown in Table 1, phosphorylation at Thr253 has no direct effect on the kinase activity of CaMKII in vitro although it has marked effects on CaMKII targeting [48]. This is unusual as most well characterised autophosphorylation events in protein kinases alter the activity of the kinase. A second unusual feature of the phosphorylation of Thr253 is that it occurs only in a small pool of cellular CaMKII. When the stoichiometry of Thr253 phosphorylation is measured in the whole brain it appears to be low and therefore of questionable functional significance. However, the phosphorylation stoichiometry is high in a specific pool of CaMKII that is associated with the PSD [48] and therefore the functional consequences of Thr253 phosphorylation may be concentrated at this and other specialised cellular locations.

Other sites, such as Ser279 and Ser314, have been found to be phosphorylated both in vitro $[47,49,50]$ and in vivo [51-53], but the stoichiometry of phosphorylation is relatively low and in vitro phosphorylation does not affect CaMKII activity. Although these sites have not been investigated for their effects on targeting, it is possible that, along with Thr253, they may belong to a new class of phosphorylation site that has its major functional role in regulating targeting rather than directly modifying enzyme activity. 
Emerging evidence from several laboratories shows that behaviour of CaMKII in vivo cannot always be predicted from our understanding of its behaviour in vitro, indicating that additional regulatory interactions occur in intact cells. One example is the understanding of the role of CaMKII in long-term potentiation (LTP). The induction of LTP in the hippocampal CA1 region requires autophosphorylation of CaMKII at Thr286 [2], and the maintenance of LTP is associated with a sustained increase in Thr286 phosphorylation [54]. Based on these findings, it was predicted that a sustained autonomous CaMKII activity produced by the sustained increase in Thr286 phosphorylation is responsible for LTP maintenance. However, CaMKII inhibitors administered after LTP induction demonstrated no consistent inhibition of LTP maintenance [55]. In addition, whilst Thr286 phosphorylation and autonomous CaMKII were both raised immediately following the induction of LTP as predicted, autonomous activity returned to basal levels within two minutes of repolarisation, whereas Thr286 phosphorylation remained elevated for at least sixty minutes [56]. Recent evidence using an independent technique (FRET imaging) has confirmed that LTP induction only increases the autonomous activity of CaMKII for two minutes [57]. In purified CaMKII in vitro, sustained Thr286 necessarily produced sustained autonomous CaMKII kinase activity. This suggests that additional interactions occur in vivo, probably involving proteins or other components of the intracellular microenvironment, to enable autonomous activity and Thr286 phosphorylation to be dissociated. One possible candidate is the endogenous CaMKII inhibitor protein, CaMKIINa, which binds CaMKII, and the expression has been shown to be upregulated during memory formation [58]. 
As Thr286 phosphorylation appears to be essential for induction and maintenance of LTP, the ability of various hippocampal brain regions to induce and maintain LTP was examined in a transgenic mouse model of CaMKII in which the CaMKII $\alpha$ is unable to be phosphorylated at Thr286 (a Thr286Ala point mutation). As expected, LTP was completely blocked in the CA1 region [2], however, LTP in the dentate gyrus remained unaffected [59]. This difference was hypothesised to be due to a mechanism involving CaMKII $\beta$, which was unaltered in the mutant mice [60]. Consistent with this idea, when LTP was measured in a transgenic mouse incapable of activating CaMKII $\beta$ ( $\beta$ CaMKII-F90G), LTP was found to be blocked in the dentate gyrus, but normal in the CA1 region of the hippocampus [61]. As both $\alpha$ and $\beta$ CaMKII are expressed in both the CA1 and dentate gyrus at similar levels, additional regulatory mechanisms controlling CaMKII function which are different between the two brain regions must exist. These may involve additional phosphorylation sites, such as Thr253, or variation in targeting protein interactions.

\section{Targeting}

There are three lines of evidence that led to the recognition of the importance of targeting in the regulation of CaMKII in cells: the differences between splice isoforms, the phenomenon of subcellular translocation and the identification of specific binding interaction with particular proteins.

Splice Isoforms. All four CaMKII genes undergo alternative splicing in their variable regions [12], which produces some variability in the kinase properties in vitro. However, the number of splice variants is much greater than the differences observed in enzyme activity and the splicing occurred in parts of the molecule well 
away from the catalytic and regulatory domains suggesting that the primary function of many of the isoforms was not to alter enzyme activity. The discovery that RNA splicing of CaMKII $\alpha$ gives rise to a truncated enzymatically inactive protein, $\alpha \mathrm{CaMKII}$-anchoring protein ( $\alpha \mathrm{KAP}$ ), which is mostly comprised of the association domain and a lipid tail, provided an unusual example of targeting. $\alpha$ KAP is found in skeletal muscle and the heart, and is expressed at low levels in the lung, kidney, and testis [62]. $\alpha \mathrm{KAP}$ can form heteromultimers with full length CaMKII, thereby targeting the active kinase subunits to the sarcoplasmic reticulum membrane in rat skeletal muscle [63]. A small number of splice variants contain a consensus nuclear localisation sequence (NLS) and others contain specific binding sites for individual proteins (for example, the binding sequence for actin is specific to the CaMKII $\beta$ isoform [64]). The fact that the association domain contains all the main sequence variations between isoforms of CaMKII suggests that most of the binding sites for other molecules are contained in this region.

A striking example of the importance of targeting to the appropriate regulation of CaMKII comes from studies of cell proliferation. In various cell types, inhibition of CaMKII has been shown to inhibit proliferation [65-67]. Indeed, in vascular smooth muscle cells in culture, proliferation and migration can be induced by serum withdrawal and this results in the specific induction of the 22 splice variant of CaMKII, despite the fact that these cells already express another isoform of

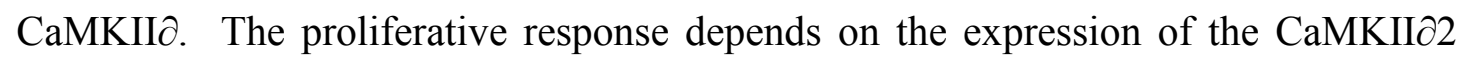
isoform and the proliferative effect can be blocked by downregulating the induced

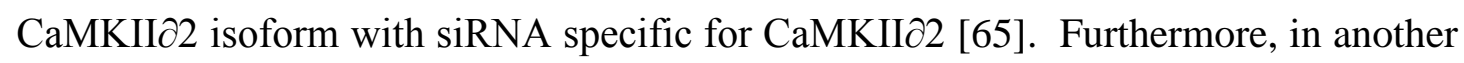
cell type, inducing the expression of an autonomously active CaMKII produced by 
truncating the molecule to remove everything from the middle of the calmodulin binding domain to the C-terminal (and hence removing most if not all of the known and proposed targeting sequences) produced aberrant results: inhibiting rather than stimulating proliferation [68].

Translocation. CaMKII translocation to the PSD has been well characterised (reviewed in [69, 70]), and CaMKII phosphorylated at different sites (Thr253, Thr286, and Thr305/306) alters the amount of CaMKII that is bound to the PSD (Table 1). Subcellular targeting of kinases, phosphatases, and other signalling molecules is commonly regulated by specific protein-protein interactions, and is an alternate mechanism by which CaMKII can be regulated (Figure 2).

The oldest evidence for CaMKII targeting comes from the recognition that CaMKII is highly concentrated in certain cellular locations such as the PSD and that the concentration at such sites can change by translocation from the cytoplasm. This translocation can occur rapidly in response to hypoxia or post-mortem delay and may involve self-assembly of CaMKII [71-73]. Translocation to the PSD may also occur more slowly during the normal maturation phase of brain development by a process that is sensitive to thyroid hormone [74]. Changes in the autophosphorylation of CaMKII can regulate translocation and CaMKII binding to the PSD (Table 1). Phosphorylation of Thr305/306 decreases the amount of CaMKII bound to the PSD, stimulating translocation from the PSD to the cytosol [75]. By contrast, phosphorylation of either Thr286 or Thr253 enhances binding to the PSD, stimulating translocation from the cytosol to the PSD and the effects appear to be through independent binding proteins since phosphorylation at both sites results in an additive 
effect [48]. Once located in the PSD, CaMKII can phosphorylate many different substrates, including subunits of the NMDA receptor [42, 76-78].

CaMKII is also concentrated at other subcellular sites, such as the cytoskeleton, where translocation has been shown to occur $[79,80]$. Phosphorylation of CaMKII at Thr286 enhances binding to MAP-2 when compared to non-phosphorylated CaMKII [81, 82], or CaMKII phosphorylated at Thr253 (Skelding et al, manuscript in preparation). However, the effects on CaMKII translocation to the cytoskeleton following Thr286, Thr305/306, and Thr253 phosphorylation have not been characterised.

Binding Partners. It is well established that the appropriate targeting of signalling molecules plays an important role in establishing the cellular responses to extracellular stimuli. With respect to CaMKII function, CaMKII must be co-localised with the correct binding protein to provide the appropriate cellular response. The specific binding proteins responsible for the translocation of CaMKII, the isoform specific interactions and the targeting to different subcellular locations are progressively being identified. Table 2 summarises the main binding proteins that have been identified.

Targeting can achieve localised functional outcomes in one of two ways, which may occur together or independently (Figure 2). Binding proteins can target the kinase activity of CaMKII to specific target proteins (substrates) in the immediate vicinity of the binding protein (or the binding protein itself), thereby resulting in a more rapid or selective phosphorylation of key functional proteins (Figure 2 top left). Interactions 
with some binding proteins can alter the activity of CaMKII through allosteric mechanisms enabling it to phosphorylate substrate proteins in vivo that are only poorly phosphorylated in vitro [76, 83, 84]. Alternatively, binding proteins can utilise the specific binding properties of CaMKII independent of its kinase activity to target the adaptor activity of CaMKII recruiting other proteins to build a signalling complex at a specific location in the cell (Figure 2 top right). This adaptor activity of CaMKII may not necessarily result in phosphorylation of any of the assembled proteins in the signalling complex.

\section{Figure 2 here}

Studies utilising proteometric techniques have identified more than thirty protein substrates for CaMKII in the PSD alone [51, 85, 86]. Numerous other binding partners have been identified, with many of the binding interactions being altered following CaMKII phosphorylation (Table 2). The existence of binding between CaMKII and the proteins listed in Table 2 has been established by overlay binding assays or immunoprecipitation/pull down assays. Most of the interactions were only examined using one isoform of CaMKII, unless otherwise stated.

\section{Table 2 here}

A few of the binding sequences on CaMKII responsible for interacting with other proteins are well characterised, such as the NLS [87]. However, most binding sequences are unknown. Except for the CaMKII $\beta m$ splice insert, which contains a 
putative SH3-domain binding region [63, 88], CaMKII does not contain the well known consensus-binding motifs. It is known that multiple parts of CaMKII can be involved in the binding interactions - with the exception of $\alpha$-actinin-2, which binds to CaMKII $\alpha$ monomers that lack the $\mathrm{C}$ terminal half of the molecule [89], all the identified sites are in the C-terminal half of the molecule. For example, BAALC-1-68 (Brain and Acute Leukaemia Cytoplasmic protein) interacts with the C-terminal end of the regulatory domain of CaMKII $\alpha$ [90], F-actin binds to CaMKII $\beta$ in the V1 insert region of the association domain [91], and the small C-terminal domain phosphatase 3 (SCP3) binds to the association domain of the G-2 variant of CaMKII $\gamma$ [92]. Therefore, the isoform, splice variant, and phosphorylation state of CaMKII can all influence the interactions between the kinase and its binding partners.

Phosphatases. The actions of protein phosphatases can play a significant role in regulating CaMKII by removing the effects of autophosphorylation of CaMKII, as well as the effects of phosphorylation of its substrates and binding partners. PP1, PP2A, and PP2C, but not PP2B, exhibit activity towards Thr286 in vitro [43, 93, 94]. Although specific phosphatases acting on the Thr305/306 phosphorylation sites have not been identified, decreased PP1 and PP2A phosphatase activity in hippocampal extracts were observed in a mouse model of Angelman's mental retardation syndrome, a model that is characterised by elevated phosphorylation at Thr305/306 [95].

CaMKII associated with PSDs is primarily dephosphorylated by PP1 [43, 93, 94, 96], although phosphorylation specifically at Thr286 appears to be protected from dephosphorylation by PSD resident PP1 [97], presumably due to steric hindrance or 
conformational change caused by neighbouring proteins. By contrast, soluble CaMKII appears to be dephosphorylated by PP2A [43]. Therefore, CaMKII may be exposed to different levels of phosphatase activity, or even to distinct phosphatases, in discrete subcellular locations. This highlights the importance of the cellular microenvironment in the regulation of CaMKII activity and function in vivo.

\section{MOLECULAR ENVIRONMENT AND CaMKII FUNCTION}

It has been well established that CaMKII located in different subcellular compartments behaves differently (reviewed in [70]), and hence the association of CaMKII with various binding partners can alter the phosphorylation and function of CaMKII. Two binding proteins that are enriched at the PSD (namely the NMDA receptor and CASK) illustrate the reciprocal interactions between CaMKII phosphorylation and CaMKII targeting. Once synaptic activity has opened NMDA receptor channels and raised intracellular calcium levels in the post-synaptic spine and local dendrite, calmodulin activates CaMKII in the vicinity, leading to phosphorylation at Thr286 and binding to the NR2B subunit of the NMDA receptor [76, 83]. This binding changes the conformation of CaMKII, keeping it autonomously active even after calcium levels fall, calmodulin dissociates, and phosphatases dephosphorylate Thr286. Additionally, autonomous phosphorylation of Thr305/306 (that would occur rapidly in purified CaMKII) is inhibited, which allows the NR2B bound CaMKII to bind calmodulin again following an increase in calcium levels [83]. In contrast, CaMKII binding to the scaffold protein CASK results in a very different outcome. Whilst CASK binding also changes the conformation of CaMKII, keeping it autonomously active, the conformation is changed in a way that favours autophosphorylation of Thr305/306 [84]. When calcium levels fall and 
calmodulin dissociates revealing the Thr305/306 site, the CASK-bound CaMKII becomes phosphorylated on Thr305/306, dissociating CaMKII from CASK and releasing a pool of CaMKII insensitive to changes in calcium levels. Until phosphatase activity can restore the ability of these kinase molecules to become activated by calcium/calmodulin, this interaction leads to an accumulation of a pool of CaMKII insensitive to changes in calcium levels. It has been hypothesised that this interaction provides a mechanism for downregulating the calcium-stimulatable pool of CaMKII, and may be important for differentiating active and inactive synapses [84]. These scenarios highlight the complexity of CaMKII regulation, and demonstrate the importance of molecular environment and the interaction with binding partners in controlling CaMKII function.

As phosphorylation of CaMKII at Thr253 does not alter CaMKII activity [48] (Table 1), the functional effects elicited following Thr253 phosphorylation are most likely due to changes in interactions with binding partners. There is indirect evidence that suggests allosteric changes caused by the environment (either alterations in the intracellular environment or changes in subcellular location) can bias phosphorylation towards Thr253 or Thr286. For example, purified soluble CaMKII incubated in the presence of calcium/calmodulin and $100 \mu \mathrm{M}$ ATP is rapidly phosphorylated at Thr286 but only very slowly at Thr253 whereas, in the presence of calcium/calmodulin and $10 \mu \mathrm{M}$ ATP, phosphorylation is biased towards Thr253 [48, 49]. However, PSDassociated CaMKII incubated with $100 \mu \mathrm{M}$ ATP autophosphorylates Thr253 at a relatively rapid rate, even in the absence of added calmodulin [98]. 
We have developed a semi-quantitative assay using a far western overlay technique with target proteins immobilised on PVDF membranes and overlaid with FLAGtagged phospho-mimic mutants of CaMKII (Thr253Asp and Thr286Asp) to detect CaMKII binding partners whose interaction with CaMKII is sensitive to Thr253 phosphorylation (Skelding et al, manuscript in preparation). From binding studies with CaMKII $\alpha$ and tissue extracts and purified proteins we have begun to investigate the effect of site specific phosphorylation at Thr286 and Thr253 (using phosphomimic mutations to simulate phosphorylation) on the ability of CaMKII to bind to its binding proteins. We have shown that phosphorylation at either Thr253 or Thr286 can enhance, inhibit or have no effect on the binding of CaMKII to particular proteins. The effects of phosphorylation at these sites on binding to proteins are independent of each other. The binding interaction with CaMKII is also sensitive to changes in phosphorylation of the binding protein. For instance, the cytoskeletal protein desmin binds non-phosphorylated CaMKII $\alpha$ and the binding is enhanced by phosphorylation at either Thr253 or Thr286. In contrast, Thr253 phosphorylation completely blocks CaMKII $\alpha$ binding to the membrane protein MBP (myelin basic protein), whilst Thr286 phosphorylation only slightly inhibits binding. Since oligodendrocytes are not known to express CaMKII $\alpha$, this interaction either does not occur in vivo, or occurs via a region of CaMKII that is conserved among all isoforms as, interestingly, MBP also binds CaMKII $\gamma$ [99]. Furthermore, the sequence of CaMKII $\gamma$ differs from that of CaMKII $\alpha$ mainly in the V1 region indicating that this region does not contain the MBP binding site. Thr286 phosphorylation stimulates CaMKII $\alpha$ binding to several microtubule-associated proteins while Thr253 phosphorylation has little or no effect. For both BAALC 1-6-8, a membrane targeting protein [90] and the enzyme TH2 (human tyrosine hydroxylase isoform 2), Thr253 
phosphorylation enhances CaMKII $\alpha$ binding, though the enhancement is stronger for BAALC (Skelding et al, manuscript in preparation). However, phosphorylation of TH2 at Ser19 and Ser40 greatly enhanced the affinity of TH2 binding by all forms of CaMKII $\alpha$ and magnified the relative enhancement of binding by Thr253 phosphorylation. The Thr253Asp phospho-mimic mutation had no effect on the kinetics of TH2 phosphorylation by CaMKII [48] indicating that for its interaction with TH2, phosphorylation at Thr253 modifies the adaptor activity of CaMKII.

We have shown that treatment of tissue extracts with exogenous protein phosphatase greatly reduced CaMKII $\alpha$ binding to many, though not all, proteins. This shows that the regulation of CaMKII binding by the phosphorylation of either (or both) CaMKII and its binding partner is not restricted to TH2 but, rather, is a widespread control mechanism. By comparing CaMKII binding profiles of tissue extracts from different brain regions or different cell lines we have also shown that the expression pattern of CaMKII binding proteins varies with cell type (Skelding et al, manuscript in preparation). Such cell specific variation in the expression of binding proteins may be involved in the targeting mechanisms responsible for producing cell specific functional consequences of CaMKII activation.

Figure 3 shows a schematic diagram that summarises a working hypothesis of how the functional consequences of CaMKII activation by a rise in intracellular calcium can be determined by the local molecular microenvironment and selectively located binding proteins. While the bulk of cellular CaMKII may undergo autophosphorylation at both Thr286 and Thr253 (centre top), there are specific pools of CaMKII that may selectively autophosphorylate at only Thr286 (top left) or 
Thr253 (top right) due to the influence of local binding proteins ( $\mathrm{a}$ and $\mathrm{b}$ ). These differentially phosphorylated pools of CaMKII could then exchange binding protein partners and/or recruit new ones (c and d) resulting in differential targeting of the CaMKII in these pools and different functional outcomes. Thus, the complement of CaMKII binding proteins expressed by a cell and their subcellular location could determine the functional consequences of CaMKII activation in that cell.

\section{Figure 3 here}

\section{CONCLUSIONS AND FUTURE DIRECTIONS}

The regulation of CaMKII is complex. Emerging evidence suggests that regulatory mechanisms controlling CaMKII in vitro are an incomplete guide to the observed behaviour of CaMKII in vivo because additional mechanisms regulating CaMKII exist in cells that cannot be seen with purified enzyme in vitro. Thr253 may represent a new class of phosphorylation sites that does not directly alter kinase activity but rather modifies its interactions with binding proteins, thereby varying the cellular location of CaMKII. CaMKII located in different molecular environments can respond to stimuli differently, and become phosphorylated at different sites resulting in differential targeting and functional outcomes. Variations in expression and intracellular location of binding proteins can give rise to cell specific functional responses to CaMKII activation.

Recent discoveries concerning interacting proteins and selective binding offer new insights into the role of binding proteins in regulating CaMKII in vivo. Future investigations will need to focus on characterising these interactions, and identifying the sites on CaMKII and/or the binding protein through which these interactions 
occur. The structural features of these binding sites could then be utilised to formulate novel small molecular weight molecules capable of selectively inhibiting the interactions between CaMKII and particular binding partners thereby interfering with the signalling pathways involved. This approach may then be able to selectively alter particular functional outcomes observed following CaMKII activation. 


\section{ACKNOWLEDGEMENTS}

This work was supported by the National Health and Medical Research Council of Australia and the Hunter Medical Research Institute. The authors would like to thank A/Prof Philip W. Dickson for his helpful comments during the preparation of this manuscript. 


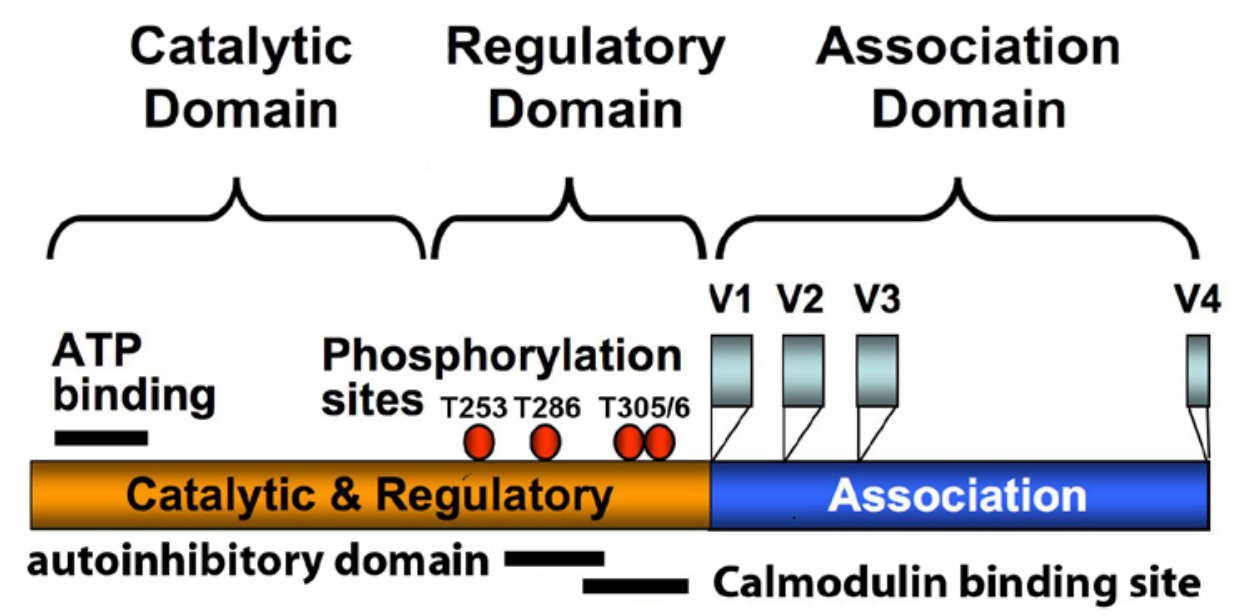

Figure 1. Schematic diagram of the domain structure of CaMKII monomers. Each isoform of CaMKII can be divided into three domains: a N-terminal catalytic domain, a regulatory domain, and a C-terminal association domain. There are four main variable regions (V1 - 4), which are the major sites of sequence variation between the genes for the main isoforms, and are also the primary sites for alternative splicing. 


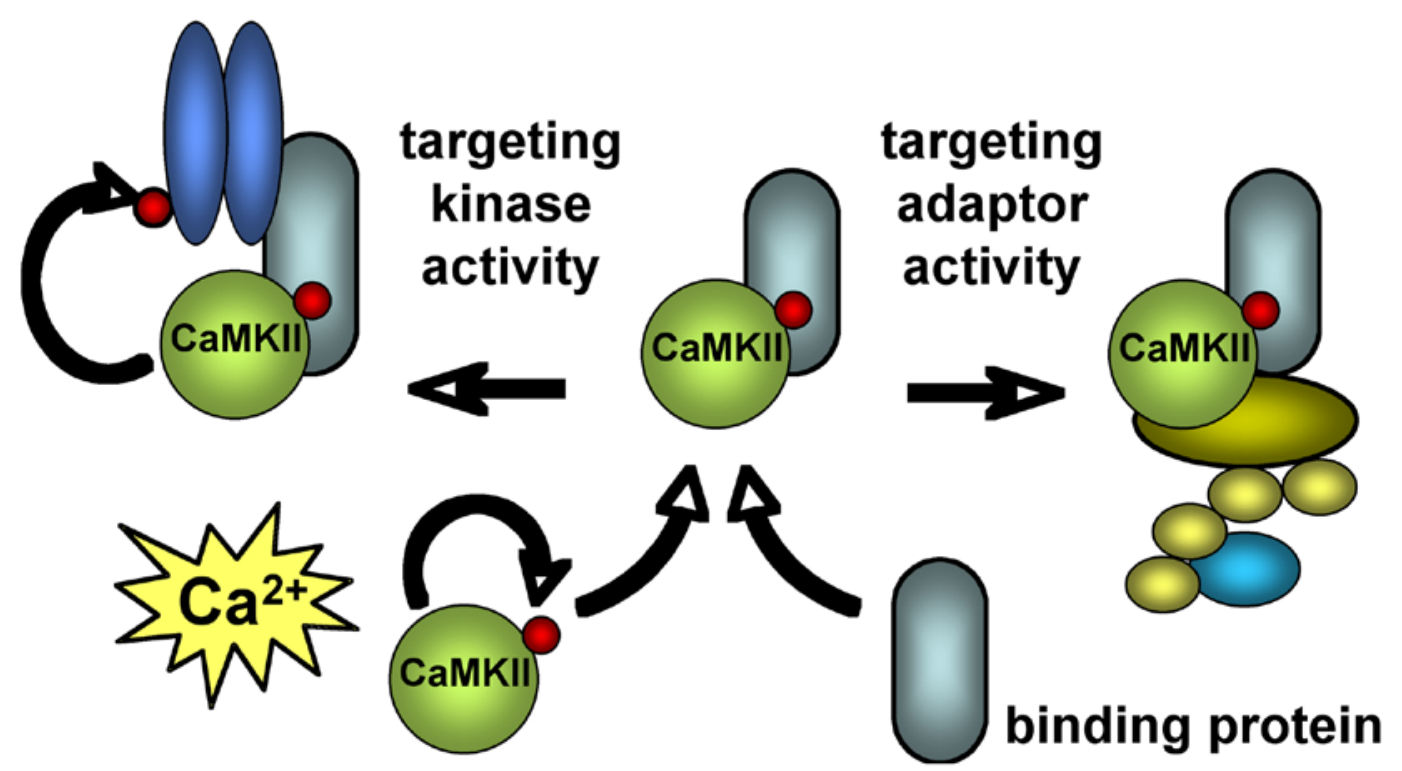

Figure 2. Targeting can achieve localised functional outcomes by targeting kinase or binding activity. The two targeting activities can operate in concert or independently but, for clarity, they are shown in the diagram as if they were mutually exclusive. 


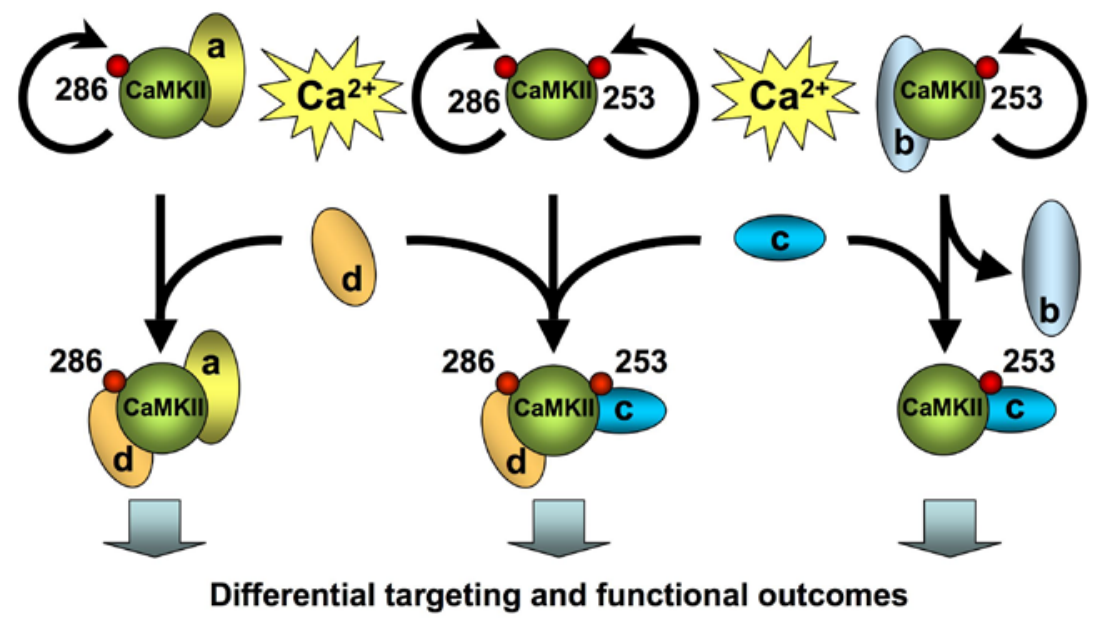

Figure 3. CaMKII in different molecular environments responds to stimuli differently. 
Table 1. Effects of autophosphorylation at threonine 286, 305/306, and 253 on CaMKII activity and targeting

\begin{tabular}{|c|c|c|c|c|c|}
\hline \multirow{2}{*}{$\begin{array}{c}\text { Site of } \\
\text { Autophosphorylation }\end{array}$} & \multicolumn{2}{|c|}{ Effect on Purified CaMKII In Vitro } & \multicolumn{2}{|c|}{$\begin{array}{c}\text { Effects on Targeting } \\
\text { to: }\end{array}$} \\
\cline { 2 - 5 } & $\begin{array}{c}\text { Calcium/ } \\
\text { Calmodulin } \\
\text { Binding }\end{array}$ & $\begin{array}{c}\text { Calcium/ } \\
\text { Calmodulin } \\
\text { Dependent } \\
\text { Activity }\end{array}$ & $\begin{array}{c}\text { Calcium/ } \\
\text { Calmodulin } \\
\text { Independent } \\
\text { Activity }\end{array}$ & $\begin{array}{c}\text { Post- } \\
\text { Synaptic } \\
\text { Density }\end{array}$ & $\begin{array}{c}\text { Other } \\
\text { Sites }\end{array}$ \\
\hline Thr286 & Increased & Prolonged & Increased & Increased & Multiple \\
\hline Thr305/306 & Decreased & Decreased & No effect & Decreased & $\begin{array}{c}\text { Not } \\
\text { examined }\end{array}$ \\
\hline Thr253 & No effect & No effect & No effect & Increased & Multiple \# \\
\hline
\end{tabular}

\# Skelding et al, manuscript in preparation 
Table 2. Proteins that Bind to CaMKII

\begin{tabular}{|c|c|c|c|c|}
\hline \multicolumn{2}{|c|}{ Binding Protein } & \multicolumn{2}{|c|}{ CaMKII Used in Study } & \multirow[b]{2}{*}{ Ref } \\
\hline Protein & Function & Phosphorylation State & Isoform & \\
\hline$\alpha$-actinin-1 & $\begin{array}{l}\text { Microfilament } \\
\text { protein }\end{array}$ & Non-phosphorylated & $\begin{array}{c}\alpha \\
(\beta, \gamma, \partial \mathrm{nt})\end{array}$ & [100] \\
\hline$\alpha$-actinin-2 & $\begin{array}{l}\text { Microfilament } \\
\text { protein }\end{array}$ & $\begin{array}{c}\text { Autophosphorylated } \\
\text { (radiolabelled CaMKII) }\end{array}$ & $\begin{array}{c}\alpha \\
(\beta, \gamma, \partial \mathrm{nt})\end{array}$ & [89] \\
\hline BAALC 1-6-8 & $\begin{array}{l}\text { Marker of human } \\
\text { hematopoietic } \\
\text { progenitor cells }\end{array}$ & $\begin{array}{l}\text { Non-phosphorylated and } \\
\text { Asp286 CaMKII binds, } \\
\text { Asp253 increases } \\
\text { binding }\end{array}$ & $\begin{array}{c}\alpha \text { binds, } \beta \\
\text { does not } \\
(\gamma, \partial \mathrm{nt})\end{array}$ & $\begin{array}{c}{[90]} \\
\dagger\end{array}$ \\
\hline $\begin{array}{l}\text { Calcium channel } \\
\alpha \text {-subunit } \\
\text { isoforms (L-type) }\end{array}$ & Calcium influx & $\begin{array}{l}\text { Non-phosphorylated } \\
\text { CaMKII binds } \alpha 1, \alpha 2 \mathrm{a}, \\
\alpha 3 \text {, and } \alpha 4 \text {, while } \\
\text { pThr } 286 \text { only binds } \alpha 1 \\
\text { and } \alpha 2 \mathrm{a}\end{array}$ & $\begin{array}{c}\partial 2 \\
(\alpha, \beta, \gamma \mathrm{nt})\end{array}$ & [101] \\
\hline $\begin{array}{c}\text { Calcium channel, } \\
\text { N-type }\end{array}$ & $\begin{array}{c}\text { Pre-synaptic } \\
\text { calcium influx }\end{array}$ & Non-phosphorylated & $\begin{array}{c}\text { Not } \\
\text { specified }\end{array}$ & [102] \\
\hline Camguk/CASK & $\begin{array}{l}\text { Synaptic protein } \\
\text { targeting and } \\
\text { synaptic plasticity }\end{array}$ & $\begin{array}{c}\text { Non-phosphorylated } \\
\text { CaMKII binds Camguk, } \\
\text { pThr305/306 decreases } \\
\text { binding } \\
\end{array}$ & $\begin{array}{c}\text { Not } \\
\text { specified }\end{array}$ & {$[84]$} \\
\hline CARMA1 & $\begin{array}{l}\text { Regulator of NFKB } \\
\text { activation of } \\
\text { lymphocytes }\end{array}$ & $\begin{array}{c}\text { Autophosphorylated } \\
\text { (radiolabelled CaMKII) }^{\#}\end{array}$ & $(\alpha, \beta, \partial \mathrm{nt})$ & [103] \\
\hline $\begin{array}{l}\text { Cdk5 activators } \\
\text { p35 and p39 }\end{array}$ & $\begin{array}{c}\text { Proline-directed } \\
\text { serine/threonine } \\
\text { kinase }\end{array}$ & Non-phosphorylated & $\begin{array}{c}\alpha \\
(\beta, \gamma, \partial \mathrm{nt})\end{array}$ & [100] \\
\hline $\begin{array}{c}\text { Cytoplasmic } \\
\text { polyadenylation } \\
\text { element binding } \\
\text { protein (CPEB) }\end{array}$ & $\begin{array}{l}\text { Regulates protein } \\
\text { synthesis and } \\
\text { initiates mRNA } \\
\text { polyadenylation } \\
\text { and translation } \\
\end{array}$ & pThr286 & $\begin{array}{c}\text { Not } \\
\text { specified }\end{array}$ & [104] \\
\hline Densin-180 & $\begin{array}{c}\text { Dendritic } \\
\text { scaffolding protein }\end{array}$ & $\begin{array}{c}\text { pThr286 enhances } \\
\text { binding compared to } \\
\text { non-phosphorylated } \\
\text { CaMKII }\end{array}$ & $\begin{array}{c}\alpha \\
(\beta, \gamma, \partial \mathrm{nt})\end{array}$ & {$[89,105]$} \\
\hline Desmin & $\begin{array}{c}\text { Muscle } \\
\text { intermediate } \\
\text { filament }\end{array}$ & $\begin{array}{l}\text { Non-phosphorylated } \\
\text { CaMKII binds desmin, } \\
\text { Asp286 and Asp253 } \\
\text { increases binding }\end{array}$ & $\begin{array}{l}\text { Purified } \\
\text { from rat } \\
\text { brain }\end{array}$ & $\begin{array}{c}{[81,82]} \\
\quad+\end{array}$ \\
\hline MAP-2 & $\begin{array}{l}\text { Microtubule } \\
\text { assembly }\end{array}$ & $\begin{array}{l}\text { Non-phosphorylated } \\
\text { binds MAP-2, Asp286 } \\
\text { increases binding }\end{array}$ & $\begin{array}{l}\text { Purified } \\
\text { from rat } \\
\text { brain }\end{array}$ & $\begin{array}{c}{[81,82]} \\
+\end{array}$ \\
\hline \multirow{3}{*}{$\begin{array}{l}\text { Myelin Basic } \\
\text { Protein }\end{array}$} & \multirow[b]{2}{*}{$\begin{array}{l}\text { Major myelin } \\
\text { sheath protein }\end{array}$} & $\begin{array}{c}\text { Autophosphorylated } \\
\text { (radiolabelled CaMKII) }^{\#}\end{array}$ & $\begin{array}{c}\gamma \\
(\alpha, \beta, \partial \mathrm{nt})\end{array}$ & [99] \\
\hline & & $\begin{array}{l}\text { Non-phosphorylated } \\
\text { binds, Asp286 slightly } \\
\text { decreases binding, } \\
\text { Asp253 completely } \\
\text { blocks binding } \\
\end{array}$ & $\begin{array}{c}\alpha \\
(\beta, \gamma, \partial \mathrm{nt})\end{array}$ & $\dagger$ \\
\hline & Voltage sensitive & pThr286 enhances & & \\
\hline
\end{tabular}




\begin{tabular}{|c|c|c|c|c|}
\hline NR2A/B & $\begin{array}{c}\text { ionotropic } \\
\text { glutamate receptor } \\
\text { involved in } \\
\text { synaptic plasticity }\end{array}$ & $\begin{array}{c}\text { binding compared to } \\
\text { non-phosphorylated } \\
\text { CaMKII }\end{array}$ & $\begin{array}{c}\alpha \\
(\beta, \gamma, \partial \mathrm{nt})\end{array}$ & $\begin{array}{c}{[42,60-} \\
62]\end{array}$ \\
\hline PP2A & $\begin{array}{c}\text { Serine/threonine } \\
\text { protein } \\
\text { phosphatase }\end{array}$ & Non-phosphorylated & $\begin{array}{c}\alpha \\
(\beta, \gamma, \partial \mathrm{nt})\end{array}$ & [106] \\
\hline Projectin & $\begin{array}{l}\text { Integral protein of } \\
\text { insect flight muscle }\end{array}$ & $\begin{array}{c}\text { pThr286 decreases } \\
\text { binding compared to } \\
\text { non-phosphorylated } \\
\text { CaMKII }\end{array}$ & $\begin{array}{c}\text { Purified } \\
\text { from rat } \\
\text { brain }\end{array}$ & [107] \\
\hline Rad & $\begin{array}{l}\text { GTP binding } \\
\text { protein }\end{array}$ & $\begin{array}{c}\text { Autophosphorylated } \\
\text { (radiolabelled CaMKII) }\end{array}$ & $\begin{array}{c}\text { Not } \\
\text { specified }\end{array}$ & [108] \\
\hline SCP3 & $\begin{array}{l}\text { PP2C-type } \\
\text { protein } \\
\text { phosphatase }\end{array}$ & Non-phosphorylated & $\begin{array}{c}\gamma(\mathrm{G}-2 \\
\text { variant }) \\
(\alpha, \beta, \partial \mathrm{nt})\end{array}$ & [92] \\
\hline STOP & $\begin{array}{c}\text { Microtubule } \\
\text { associated protein }\end{array}$ & pThr286 & $\begin{array}{l}\text { Purified } \\
\text { from rat } \\
\text { brain }\end{array}$ & [109] \\
\hline Synapsin 1 & $\begin{array}{l}\text { Synaptic vesicle } \\
\text { binding protein }\end{array}$ & $\begin{array}{c}\text { Autophosphorylated } \\
\text { (radiolabelled CaMKII) }\end{array}$ & $\begin{array}{c}\alpha \\
(\beta, \gamma, \partial \mathrm{nt})\end{array}$ & [110] \\
\hline Syntaxin $1 \mathrm{~A}$ & $\begin{array}{l}\text { Component of } \\
\text { exocytotic } \\
\text { molecular } \\
\text { machinery }\end{array}$ & $\begin{array}{l}\text { Only pThr286 bound } \\
\text { syntaxin 1A (non- } \\
\text { phosphorylated CaMKII } \\
\text { did not interact) }\end{array}$ & $\begin{array}{c}\alpha \\
(\beta, \gamma, \partial \mathrm{nt})\end{array}$ & [111] \\
\hline Tau & $\begin{array}{l}\text { Microtubule } \\
\text { assembly }\end{array}$ & $\begin{array}{l}\text { Non-phosphorylated and } \\
\text { Asp253 CaMKII bind } \\
\text { tau, Asp286 increases } \\
\text { binding }\end{array}$ & $\begin{array}{c}\text { Purified } \\
\text { from rat } \\
\text { brain }\end{array}$ & $\begin{array}{c}{[82,112]} \\
+\end{array}$ \\
\hline $\begin{array}{c}\text { Tyrosine } \\
\text { hydroxylase (rat) }\end{array}$ & $\begin{array}{l}\text { Catecholamine } \\
\text { biosynthesis }\end{array}$ & Non-phosphorylated & $\begin{array}{c}\alpha \\
(\beta, \gamma, \partial \mathrm{nt})\end{array}$ & [113] \\
\hline $\begin{array}{c}\text { Tyrosine } \\
\text { hydroxylase } \\
\text { isoform } 2 \\
\text { (human) } \\
\end{array}$ & $\begin{array}{l}\text { Catecholamine } \\
\text { biosynthesis }\end{array}$ & $\begin{array}{l}\text { Non-phosphorylated and } \\
\text { Asp286 CaMKII bind, } \\
\text { Asp253 increases } \\
\text { binding } \\
\end{array}$ & $\begin{array}{c}\alpha \\
(\beta, \gamma, \partial \mathrm{nt})\end{array}$ & $\dagger$ \\
\hline $\begin{array}{c}\text { Tyrosine } \\
\text { hydroxylase } \\
\text { isoform } 2 \\
\text { (human), } \\
\text { phosphorylated at } \\
\text { Ser19 and Ser40 }\end{array}$ & $\begin{array}{l}\text { Catecholamine } \\
\text { biosynthesis }\end{array}$ & $\begin{array}{l}\text { Binding is enhanced for } \\
\text { non-phosphorylated, } \\
\text { Asp286, and Asp253 } \\
\text { CaMKII when compared } \\
\text { to non-phosphorylated } \\
\text { tyrosine hydroxylase }\end{array}$ & $\begin{array}{c}\alpha \\
(\beta, \gamma, \partial \mathrm{nt})\end{array}$ & $\dagger$ \\
\hline
\end{tabular}

nt not tested

\# When autophosphorylated, CaMKII will be predominantly (though not always exclusively) phosphorylated at Thr286

tSkelding et al, manuscript in preparation 


\section{REFERENCES}

(1) Miller SG, Kennedy MB (1985) Distinct forebrain and cerebellar isozymes of type II Ca2+/calmodulin-dependent protein kinase associate differently with the postsynaptic density fraction. J Biol Chem 260:9039-46.

(2) Giese KP, Fedorov NB, Filipkowski RK, Silva AJ (1998) Autophosphorylation of Thr286 of the alpha calcium-calmodulin kinase II in LTP and learning. Science 279:870-3.

(3) Miller S, Yasuda M, Coats SK, Jones Y, Martine ME, Mayford M (2002) Disruption of dendritic translation of CaMKIIalpha impairs stabilization of synaptic plasticity and memory consolidation. Neuron 36:507-19.

(4) Soderling TR, Derkach VA (2000) Postsynaptic protein phosphorylation and LTP. Trends Neurosci 23:75-80.

(5) Taha S, Hanover SL, Silva AJ, Stryker MP (2002) Autophosphorylation of alphaCaMKII is required for ocular dominance plasticity. Neuron 36:483-91.

(6) Cao X, Wang H, Mei B, An S, Yin L, Wang LP, Tsien JZ (2008) Inducible and selective erasure of memories in the mouse brain via chemical-genetic manipulation. Neuron 60:353-66.

(7) von Hertzen LSJ, Giese KP (2005) Alpha-isoform of Ca2+/calmodulin-dependent kinase II autophosphorylation is required for memory consolidation-specific transcription. Neuroreport 16:1411-14.

(8) Jones KT (2007) Intracellular calcium in the fertilization and development of mammalian eggs. Clin Exp Pharmacol Physiol 34:1084-9.

(9) Shin MK, Kim MK, Bae YS, Jo I, Lee SJ, Chung CP, Park YJ, Min do S (2008) A novel collagen-binding peptide promotes osteogenic differentiation via Ca2+/calmodulin-dependent protein kinase II/ERK/AP-1 signaling pathway in human bone marrow-derived mesenchymal stem cells. Cell Signal 20:613-24.

(10) Munevar S, Gangopadhyay SS, Gallant C, Colombo B, Sellke FW, Morgan KG (2008) CaMKIIT287 and T305 regulate history-dependent increases in alpha agonist-induced vascular tone. J Cell Mol Med 12:219-26.

(11) Hudmon A, Schulman H (2002) Structure-function of the multifunctional Ca2+/calmodulin-dependent protein kinase II. Biochem J 364:593-611.

(12) Hudmon A, Schulman H (2002) Neuronal Ca2+/calmodulin-dependent protein kinase II: the role of structure and autoregulation in cellular function. Annu Rev Biochem 71:473-510.

(13) Elgersma Y, Sweatt JD, Giese KP (2004) Mouse genetic approaches to investigating calcium/calmodulin-dependent protein kinase II function in plasticity and cognition. J Neurosci 24:8410-5.

(14) Hu BR, Kamme F, Wieloch T (1995) Alterations of Ca2+/calmodulin-dependent protein kinase II and its messenger RNA in the rat hippocampus following normo- and hypothermic ischemia. Neurosci 68:1003-16.

(15) Mengesdorf T, Althausen S, Mies G, Olah L, Paschen W (2002) Phosphorylation state, solubility, and activity of calcium/calmodulin-dependent protein kinase II alpha in transient focal ischemia in mouse brain. Neurochem Res 27:471-84.

(16) Gurd JW, Rawof S, Huo JZ, Dykstra C, Bissoon N, Teves L, Wallace MC, Rostas JAP (2008) Ischemia and status epilepticus result in enhanced phosphorylation of calcium and calmodulin stimulated protein kinase II on threonine 253. Brain Res 1218:158-65. 
(17) Amada N, Aihara K, Ravid R, Horie M (2005) Reduction of NR1 and phosphorylated $\mathrm{Ca}+/$ calmodulin-dependent protein kinase II levels in Alzheimer's disease. Neuroreport 16:1809-13.

(18) Wang JZ, Grundke-Iqbal I, Iqbal K (2007) Kinases and phosphatases and tau sites involved in Alzheimer neurofibrillary degeneration. Eur J Neurosci 25:59-68.

(19) Xiao J, Perry G, Troncoso J, Monteiro MJ (1996) alpha-calcium-calmodulindependent kinase II is associated with paired helical filaments of Alzheimer's disease. J Neuropathol Exp Neurol 55:954-63.

(20) McNamara JO, Huang YZ, Leonard AS (2006) Molecular signaling mechanisms underlying epileptogenesis. Sci STKE 2006:re12.

(21) Zeitz KP, Giese KP, Silva AJ, Basbaum AI (2004) The contribution of autophosphorylated alpha-calcium-calmodulin kinase II to injury-induced persistent pain. Neurosci 128:889-98.

(22) Picconi B, Gardoni F, Centonze D, Mauceri D, Cenci MA, Bernardi G, Calabresi P, Di Luca M (2004) Abnormal Ca2+-calmodulin-dependent protein kinase II function mediates synaptic and motor deficits in experimental parkinsonism. J Neurosci 24:5283-91.

(23) Colbran RJ, Smith MK, Schworer CM, Fong Y-L, Soderling TR (1989) Regulatory domain of calcium/calmodulin-dependent protein kinase II. Mechanism of inhibition and regulation by phosphorylation. J Biol Chem 264:4800-4.

(24) Smith MK, Colbran RJ, Brickey DA, Soderling TR (1992) Functional determinants in the autoinhibitory domain of calcium-calmodulin dependent protein kinase II. J Biol Chem 267:1761-8.

(25) Payne ME, Fong Y-L, Ono T, Colbran RJ, Kemp BE, Soderling TR, Means AR (1988) Calcium/calmodulin-dependent protein kinase II. Characterization of distinct calmodulin binding and inhibitory domains. J Biol Chem 263:7190-5.

(26) Braun AP, Schulman H (1995) The multifunctional calcium/calmodulindependent protein kinase: from form to function. Annu Rev Physiol 57:41745.

(27) Tobimatsu T, Fujisawa H (1989) Tissue-specific expression of four types of rat calmodulin-dependent protein kinase II mRNAs. J Biol Chem 264:17907-12.

(28) Kolb SJ, Hudmon A, Ginsberg TR, Waxham MN (1998) Identification of domains essential for the assembly of calcium/calmodulin-dependent protein kinase II holoenzymes. J Biol Chem 273:31555-64.

(29) Bennett MK, Erondu NE, Kennedy MB (1983) Purification and characterization of a calmodulin-dependent protein kinase that is highly concentrated in brain. J Biol Chem 258:12735-44.

(30) Brocke L, Chiang LW, Wagner PD, Schulman H (1999) Functional implications of the subunit composition of neuronal CaM kinase II. J Biol Chem 274:22713-22.

(31) Kanaseki T, Ikeuchi Y, Sugiura H, Yamauchi T (1991) Structural features of $\mathrm{Ca} 2+/$ calmodulin-dependent protein kinase II revealed by electron microscopy. J Cell Biol 115:1049-60.

(32) Srinivasan M, Edman CF, Schulman H (1994) Alternative splicing introduces a nuclear localization signal that targets multifunctional CaM kinase to the nucleus. J Cell Biol 126:839-52.

(33) Gaertner TR, Kolodziej SJ, Wang D, Kobayashi R, Koomen JM, Stoops JK, Waxham MN (2004) Comparative analyses of the three-dimensional 
structures and enzymatic properties of alpha, beta, gamma, and delta isoforms of Ca2+/calmodulin-dependent protein kinase II. J Biol Chem 279:12484-94.

(34) Woodgett JR, Davison MT, Cohen P (1983) The calmodulin-dependent glycogen synthase kinase from rabbit skeletal muscle. Purification, subunit structure, and substrate specificity. Eur J Biochem 136:481-7.

(35) Morris EP, Torok K (2001) Oligomeric structure of alpha-calmodulin-dependent protein kinase II. J Mol Biol 308:1-8.

(36) Rosenberg OS, Deindl S, Sung RJ, Nairn AC, Kuriyan J (2005) Structure of the autoinhibited kinase domain of CaMKII and SAXS analysis of the holoenzyme. Cell 123:849-60.

(37) Meyer T, Hanson PI, Stryer L, Schulman H (1992) Calmodulin trapping by calcium-calmodulin-dependent protein kinase. Science 256:1199-202.

(38) Newton D, Klee C, Woodgett J, Cohen P (1985) Selective effects of CAPP1calmodulin on its target proteins. Biochim Biophys Acta 845:533-9.

(39) Putkey JA, Draetta GF, Slaughter GR, Klee CB, Cohen P, Stull JT, Means AR (1986) Genetically engineered calmodulins differentially activate target enzymes. J Biol Chem 261:9896-903.

(40) Colbran RJ, Schworer CM, Hashimoto Y, Fong Y-L, Rich DP, Smith MK, Soderling TR (1989) Calcium/calmodulin-dependent protein kinase II. Biochem J 258:313-25.

(41) De Koninck P, Schulman H (1998) Sensitivity of CaM kinase II to the frequency of Ca2+ oscillations. Science 279:227-30.

(42) Strack S, Colbran RJ (1998) Autophosphorylation-dependent targeting of calcium/calmodulin-dependent protein kinase II by the NR2B subunit of the N-methyl-D-aspartate receptor. J Biol Chem 273:20689-92.

(43) Strack S, Barban MA, Wadzinski BE, Colbran RJ (1997) Differential inactivation of postsynaptic density-associated and soluble Ca2+/calmodulindependent protein kinase II by protein phosphatases 1 and 2A. J Neurochem 68:2119-28.

(44) Hanson PI, Schulman H (1992) Inhibitor autophosphorylation of multifunctional Ca2+/calmodulin-dependent protein kinase analyzed by site-directed mutagenesis. J Biol Chem 267:17216-24.

(45) Patton BL, Miller SG, Kennedy MB (1990) Activation of type II calcium/calmodulin-dependent protein kinase by $\mathrm{Ca} 2+/$ calmodulin is inhibited by autophosphorylation of threonine within the calmodulin-binding domain. J Biol Chem 265:11204-12.

(46) Meador WE, Means AR, Quicho FA (1993) Modulation of calmodulin plasticity in molecular recognition of CaMKII by scaffold-dependent autophosphorylation. Science 262:1718-21.

(47) Colbran RJ, Soderling TR (1990) Calcium/calmodulin-independent autophosphorylation sites of calcium/calmodulin-dependent protein kinase II. Studies on the effect of phosphorylation of threonine 305/306 and serine 314 on calmodulin binding using synthetic peptides. J Biol Chem 265:11213-9.

(48) Migues PV, Lehmann IT, Fluechter L, Cammarota M, Gurd JW, Sim AT, Dickson PW, Rostas JA (2006) Phosphorylation of CaMKII at Thr253 occurs in vivo and enhances binding to isolated postsynaptic densities. J Neurochem 98:289-99.

(49) Hanson PI, Kapiloff MS, Lou LL, Rosenfeld MG, Schulman H (1989) Expression of a multifunctional $\mathrm{Ca} 2+/$ calmodulin-dependent protein kinase and mutational analysis of its autoregulation. Neuron 3:59-70. 
(50) Lengyel I, Fieuw-Makaroff S, Hall AL, Sim AT, Rostas JA, Dunkley PR (2000) Modulation of the phosphorylation and activity of calcium/calmodulindependent by protein kinase II by zinc. J Neurochem 75:594-605.

(51) Jaffe H, Vinade L, Dosemeci A (2004) Identification of novel phosphorylation sites on postsynaptic density proteins. Biochem Biophys Res Commun 321:210-8.

(52) Molloy SS, Kennedy MB (1991) Autophosphorylation of type II $\mathrm{Ca} 2+/$ calmodulin-dependent protein kinase in cultures of postnatal rat hippocampal slices. Proc Natl Acad Sci U S A 88:4756-60.

(53) Collins MO, Yu L, Coba MP, Hsui H, Campuzano I, Blackstock WP, Choudhary JS, Grant SG (2005) Proteomic analysis of in vivo phosphorylated synaptic proteins. J Biol Chem 280:5972-82.

(54) Ouyang Y, Kantor D, Harris KM, Schuman EM, Kennedy MB (1997) Visualization of the distribution of autophosphorylated calcium/calmodulindependent protein kinase II after tetanic stimulation in the CA1 area of the hippocampus. J Neurosci 17:5416-27.

(55) Chen HX, Otmakhov N, Strack S, Colbran RJ, Lisman JE (2001) Is persistent activity of calcium/calmodulin-dependent kinase required for the maintenance of LTP? J Neurophysiol 85:1368-76.

(56) Lengyel I, Voss K, Cammarota M, Bradshaw K, Brent V, Murphy KP, Giese KP, Rostas JA, Bliss TV (2004) Autonomous activity of CaMKII is only transiently increased following the induction of long-term potentiation in the rat hippocampus. Eur J Neurosci 20:3063-72.

(57) Lee SJ, Escobedo-Lozoya Y, Szatmari EM, Yasuda R (2009) Activation of CaMKII in single dendritic spines during long-term potentiation. Nature 458:299-304.

(58) Lepicard EM, Mizuno K, Antunes-Martins A, von Hertzen LSJ, Giese KP (2006) An endogenous inhibitor of calcium/calmodulin-dependent kinase II is upregulated during consolidation of fear memory. Eur J Neurosci 23:3063-70.

(59) Errington ML, Bradshaw KD, Peters M, Bliss TVP, Giese KP (2002) LTP is abolished in area CA1 but survives in the dentate gyrus of alphaCaMKIIT286A mutant mice: an in vivo and in vitro study. Abstr Fed Eur Soc Neurosci 3:262.

(60) Cooke SF, Wu J, Plattner F, Errington M, Rowan M, Peters M, Hirano A, Bradshaw KD, Anwyl R, Bliss TVP, Giese KP (2006) Autophosphorylation of alphaCaMKII is not a general requirement for NMDA receptor-dependent LTP in the adult mouse. J Physiol 574:805-18.

(61) Cho MH, Cao X, Wang D, Tsien JZ (2007) Dentate gyrus-specific manipulation of beta-Ca2+/calmodulin-dependent kinase II disrupts memory consolidation. Proc Natl Acad Sci U S A 104:16317-22.

(62) Sugai R, Takeuchi M, Okuno S, Fujisawa H (1996) Molecular cloning of a novel protein containing the association domain of calmodulin-dependent protein kinase II. J Biochem 120:773-9.

(63) Bayer KU, Harbers K, Schulman H (1998) alphaKAP is an anchoring protein for a novel CaM kinase II isoform in skeletal muscle. EMBO J 17:5598-605.

(64) O'Leary H, Lasada E, Bayer KU (2006) CaMKIIbeta association with the actin cytoskeleton is regulated by alternative splicing. Mol Biol Cell 17:4656-65.

(65) House SJ, Ginnan RG, Armstrong SE, Singer HA (2007) Calcium/calmodulindependent protein kinase II-delta isoform regulation of vascular smooth muscle cell proliferation. Am J Physiol Cell Physiol 292:C2276-87. 
(66) An P, Zhu JY, Yang Y, Lv P, Tian YH, Chen MK, Luo HS (2007) KN-93, a specific inhibitor of CaMKII inhibits human hepatic stellate cell proliferation in vitro. World J Gastroenterol 13:1445-8.

(67) Morris TA, DeLorenzo RJ, Tombes RM (1998) CaMK-II inhibition reduces cyclin D1 levels and enhances the association of p27kip1 with Cdk2 to cause G1 arrest in NIH 3T3 cells. Exp Cell Res 240:218-27.

(68) Planas-Silva MD, Means AR (1992) Expression of a constitutive form of calcium/calmodulin dependent protein kinase II leads to arrest of the cell cycle in G2. EMBO J 11:507-17.

(69) Schulman H (2004) Activity-dependent regulation of calcium/calmodulindependent protein kinase II localization. J Neurosci 24:8399-403.

(70) Colbran RJ (2004) Targeting of calcium/calmodulin-dependent protein kinase II. Biochem J 378:1-16.

(71) Kolb SJ, Hudmon A, Waxham MN (1995) Ca2+/calmodulin kinase II translocates in a hippocampal slice model of ischemia. J Neurochem 64:214756.

(72) Strack S, Choi S, Lovinger DM, Colbran RJ (1997) Translocation of autophosphorylated calcium/calmodulin-dependent protein kinase II to the postsynaptic density. J Biol Chem 272:13467-70.

(73) Suzuki T, Okumura-Noji K, Tanaka R, Tada T (1994) Rapid translocation of cytosolic $\mathrm{Ca} 2+/$ calmodulin-dependent protein kinase II into postsynaptic density after decapitation. J Neurochem 63:1529-37.

(74) Wang X, Rostas JA (1996) Effect of hypothyroidism on the subcellular distribution of $\mathrm{Ca} 2+/$ calmodulin-stimulated protein kinase II in chicken brain during posthatch development. J Neurochem 66:1625-32.

(75) Elgersma Y, Fedorov NB, Ikonen S, Choi ES, Elgersma M, Carvalho OM, Giese KP, Silva AJ (2002) Inhibitory autophosphorylation of CaMKII controls PSD association, plasticity, and learning. Neuron 36:493-505.

(76) Bayer KU, De Koninck P, Leonard AS, Hell JW, Schulman H (2001) Interaction with the NMDA receptor locks CaMKII in an active formation. Nature 411:801-5.

(77) Gardoni F, Caputi A, Cimino M, Pastorino L, Cattabeni F, Di Luca M (1998) Calcium/calmodulin-dependent protein kinase II is associated with NR2A/B subunits of NMDA receptor in postsynaptic densities. J Neurochem 71:173341.

(78) Gardoni F, Schrama LH, van Dalen JJW, Gispen WH, Cattabeni F, Di Luca M (1999) alphaCaMKII binding to the C-terminal tail of NMDA receptor subunit NR2A and its modulation by autophosphorylation. FEBS Lett 456:394-8.

(79) Lin YC, Redmond L (2008) CaMKIIbeta binding to stable F-actin in vivo regulates F-actin filament stability. Proc Natl Acad Sci U S A 105:15791-6.

(80) Shen K, Teruel MN, Subramanian K, Meyer T (1998) CaMKIIbeta functions as an F-actin targeting module that localizes CaMKIIalpha/beta heterooligomers to dendritic spines. Neuron 21:593-606.

(81) Jefferson AB, Schulman H (1991) Phosphorylation of microtubule-associated protein-2 in GH3 cells. Regulation by cAMP and by calcium. J Biol Chem 266:346-54.

(82) Yamamoto H, Fukunaga K, Goto S, Tanaka E, Miyamoto E (1985) Ca2+, calmodulin-dependent regulation of microtubule formation via phosphorylation of microtubule-associated protein 2, tau factor, and tubulin, 
and comparison with the cyclic AMP-dependent phosphorylation. J Neurochem 44:759-68.

(83) Bayer KU, LeBel E, McDonald GL, O'Leary H, Schulman H, De Koninck P (2006) Transition from reversible to persistent binding of CaMKII to postsynaptic sites and NR2B. J Neurosci 26:1164-74.

(84) Lu CS, Hodge JJ, Mehren J, Sun XX, Griffith LC (2003) Regulation of the Ca2+/CaM-responsive pool of CaMKII by scaffold-dependent autophosphorylation. Neuron 40:1185-97.

(85) Yoshimura Y, Aoi C, Yamauchi T (2000) Investigation of protein substrates of $\mathrm{Ca} 2+/$ calmodulin-dependent protein kinase II translocated to the postsynaptic density. Mol Brain Res 81:118-28.

(86) Yoshimura Y, Shinkaway T, Taoka M, Kobayashi K, Isobe T, Yamauchi T (2002) Identification of protein substrates of Ca2+/calmodulin-dependent protein kinase II in the postsynaptic density by protein sequencing and mass spectrometry. Biochem Biophys Res Commun 290:948-54.

(87) Heist EK, Srinivasan M, Schulman H (1998) Phosphorylation at the nuclear localization signal of $\mathrm{Ca} 2+/$ calmodulin-dependent protein kinase II blocks its nuclear targeting. J Biol Chem 273:19763-71.

(88) Urquidi V, Ashcroft SJ (1995) A novel pancreatic beta-cell isoform of calcium/calmodulin-dependent protein kinase II (beta 3 isoform) contains a proline-rich tandem repeat in the association domain. FEBS Lett 358:23-6.

(89) Robison AJ, Bass MA, Jiao Y, MacMillan LB, Carmody LC, Bartlett RK, Colbran RJ (2005) Multivalent interactions of calcium/calmodulin-dependent protein kinase II with the postsynaptic density proteins NR2B, densin-180, and alpha-actinin-2. J Biol Chem 280:35329-36.

(90) Wang X, Tian QB, Okano A, Sakagami H, Moon IS, Kondo H, Endo S, Suzuki T (2005) BAALC 1-6-8 protein is targeted to postsynaptic lipid rafts by its Nterminal myristoylation and palmitoylation, and interacts with alpha, but not beta, subunit of $\mathrm{Ca} /$ calmodulin-dependent protein kinase II. J Neurochem 92:647-59.

(91) Okamoto K, Narayanan R, Lee SH, Murata K, Hayashi Y (2007) The role of CaMKII as an F-actin-bundling protein crucial for maintenance of dendritic spine structure. Proc Natl Acad Sci U S A 104:6418-23.

(92) Gangopadhyay SS, Gallant C, Sundberg EJ, Lane WS, Morgan KG (2008) Regulation of $\mathrm{Ca} 2+/$ calmodulin kinase II by a small C-terminal domain phosphatase. Biochem J 412:507-16.

(93) Shields SM, Ingebritsen TS, Kelly PT (1985) Identification of protein phosphatase 1 in synaptic junctions: dephosphorylation of endogenous calmodulin-dependent kinase II and synapse-enriched phosphoproteins. J Neurosci 5:3414-22.

(94) Fukunaga K, Kobayashi T, Tamura S, Miyamoto E (1993) Dephosphorylation of autophosphorylated $\mathrm{Ca} 2+/$ calmodulin-dependent protein kinase II by protein phosphatase 2C. J Biol Chem 268:133-7.

(95) Weeber EJ, Jiang YH, Elgersma Y, Varga AW, Carrasquillo Y, Brown SE, Christian JM, Mirnikjoo B, Silva A, Beaudet AL, Sweatt JD (2003) Derangements of hippocampal calcium/calmodulin-dependent protein kinase II in a mouse model for Angelman mental retardation syndrome. J Neurosci 23:2634-44. 
(96) Dosemeci A, Reese TS (1993) Inhibition of endogenous phosphatase in a postsynaptic density fraction allows extensive phosphorylation of the major postsynaptic density protein. J Neurochem 61:550-5.

(97) Mullasseril P, Dosemeci A, Lisman JE, Griffith LC (2007) A structural mechanism for maintaining the 'on-state' of the CaMKII memory switch in the post-synaptic density. J Neurochem 103:357-64.

(98) Dosemeci A, Gollop N, Jaffe H (1994) Identification of a major autophosphorylation site on postsynaptic density-associated Ca2+/calmodulindependent protein kinase. J Biol Chem 269:31330-3.

(99) Shoju H, Sueyoshi N, Ishida A, Kameshita I (2005) High level expression and preparation of autonomous Ca2+/calmodulin-dependent protein kinase II in Escherichia coli. J Biochem 138:605-11.

(100) Dhavan R, Greer PL, Morabito MA, Orlando LR, Tsai LH (2002) The cyclindependent kinase 5 activators p35 and p39 interact with the alpha-subunit of $\mathrm{Ca} 2+/$ calmodulin-dependent protein kinase II and alpha-actinin-1 in a calcium-dependent manner. J Neurosci 22:7879-91.

(101) Grueter CE, Abiria SA, Wu Y, Anderson ME, Colbran RJ (2008) Differential regulated interactions of calcium/calmodulin-dependent protein kinase II with isoforms of voltage-gated calcium channel beta subunits. Biochemistry 47:1760-7.

(102) Hell JW, Appleyard SM, Yokoyama CT, Warner C, Catterall WA (1994) Differential phosphorylation of two size forms of the N-type calcium channel alpha1 subunit which have different COOH termini. J Biol Chem 269:7390-6.

(103) Ishiguro K, Green T, Rapley J, Wachtel H, Giallourakis C, Landry A, Cao Z, Lu N, Takafumi A, Goto H, Daly MJ, Xavier RJ (2006) Ca2+/calmodulindependent protein kinase II is a modulator of CARMA1-mediated NF-kappaB activation. Mol Cell Biol 26:5497-508.

(104) Atkins CM, Nozaki N, Shigeri Y, Soderling TR (2004) Cytoplasmic polyadenylation element binding protein-dependent protein synthesis is regulated by calcium/calmodulin-dependent protein kinase II. J Neurosci 24:5193-201.

(105) McNeill RB, Colbran RJ (1995) Interaction of autophosphorylated Ca2+/calmodulin-dependent protein kinase II with neuronal cytoskeletal proteins. J Biol Chem 270:10043-9.

(106) Yamashita T, Inui S, Maeda K, Hua DR, Takagi K, Fukunaga K, Sakaguchi N (2006) Regulation of CaMKII by alpha4/PP2Ac contributes to learning and memory. Brain Res 1082:1-10.

(107) Fahrmaan M, Erfmann M, Beinbrech G (2002) Binding of CaMKII to the giant muscle protein projectin: stimulation of CaMKII activity by projectin. Biochim Biophys Acta 1569:127-34.

(108) Moyers JS, Bilans PJ, Zhu J, Kahn CR (1997) Rad and Rad-related GTPases interact with calmodulin and calmodulin-dependent protein kinase II. J Biol Chem 272:11832-9.

(109) Baratier J, Peris L, Brocard J, Gory-Faure S, Dufour F, Bosc C, Fourest-Lieuvin A, Blanchoin L, Salin P, Job D, Andrieux A (2006) Phosphorylation of microtubule-associated protein STOP by calmodulin kinase II. J Biol Chem 281:19561-9.

(110) Benfenati F, Valtorta F, Rubenstein JL, Gorelick FS, Greengard P, Czernik AJ (1992) Synaptic vesicle-associated Ca2+/calmodulin-dependent protein kinase II is a binding protein for synapsin I. Nature 359:417-20. 
(111) Ohyama A, Hosaka K, Komiya Y, Akagawa K, Yamauchi E, Taniguchi H, Sasagawa N, Kumakura K, Mochida S, Yamauchi T, Igarashi M (2002) Regulation of exocytosis through $\mathrm{Ca} 2+/ \mathrm{ATP}$-dependent binding of autophosphorylated Ca2+/calmodulin-activated protein kinase II to syntaxin 1A. J Neurosci 22:3342-51.

(112) Bennecib M, Gong CX, Grundke-Iqbal I, Iqbal K (2001) Inhibition of PP-2A upregulates CaMKII in rat forebrain and induces hyperphosphorylation of tau at Ser 262/356. FEBS Lett 490:15-22.

(113) Lehmann IT, Bobrovskaya L, Gordon SL, Dunkley PR, Dickson PW (2006) Differential regulation of the human tyrosine hydroxylase isoforms via hierarchical phosphorylation. J Biol Chem 281:17644-51. 